Einnor, A. H. (1942). Aust. J. exp. Biol. med. Sci. $20,73$.

Ennor, A. H. \& Stocken, L. A. (1947). Nature, Lond., 159, 308.

Fiske, C. H. \& Subbarow, Y. (1925). J. biol. Chem. 66, 375.

Fiske, C. H. \& Subbarow, Y. (1929). J. biol. Chem. 81, 629.

Flock, E., Bollman, J. L. \& Mann, F. C. (1936a). J. biol. Chem. 115, 179.

Flock, E., Bollman, J. L. \& Mann, F. C. (1936b). J. biol. Chem. 115, 201.

Higgins, G. M., Berkson, J. \& Flock, E. (1932). Amer. J. Physiol. 102, 673.

Higgins, G. M., Berkson, J. \& Flock, E. (1933). Amer. J. Physiol. 105, 177.

Kalckar, H. M. (1945). Ann. Rev. Biochem. 14, 283.

Kaplan, N. O. \& Greenberg, D. M. (1943). J. biol. Chem. 150, 479.

Kaplan, N. O. \& Greenberg, D. M. (1944a). J. biol. Chem. 156, 525 .

Kaplan, N. O. \& Greenberg, D. M. (1944b). J. biol. Chem. 156, 543.

Kaplan, N. O. \& Greenberg, D. M. (1944c). J. biol. Chem. 156, 511.

Kosterlitz, H. W. \& Ritchie, C. M. (1943). Biochem. J. 37, 181.

Lehninger, A. L. (1944). J. biol. Chem. 154, 309.

Lehninger, A. L. (1945a). J. biol. Chem. 161, 437.

Lehninger, A. L. (1945b). J. biol. Chem. 157, 363.

Le Page, G. A. (1946). Amèr. J. Physiol. 146, 267.
Le Page, G. A. \& Umbreit, W. W. (1945). In Manometric Techniques and Related Methods for the Study of Tissue Metabolism, by W. W. Umbreit, R. H. Burris \& J. F. Stauffer. Minneapolis: Burgess Publishing Co.

Lipmann, F. (1941). In Advances in Enzymology and Related Subjects, 1, 99, ed. by Nord, F. F. \& Werkman, C. H. New York: Interscience Publishers Inc.

Lipmann, F. \& Tuttle, L. C. (1944). J. biol. Chem. 153, 571. Lipmann, F. \& Tuttle, L. C. (1945). J. biol. Chem. 159, 21. Markham, R. (1942). Biochem. J. 36, 790.

Meier, R. \& Thoenes, E. (1933). Arch. exp. Path. Pharmak. $169,655$.

Meijbaum, W. (1939). Hoppe-Seyl. Z. 258, 117.

Munoz, J. M. \& Leloir, L. F. (1943). J. biol. Chem. 147, 355.

Nelson, N., Rapoport, S., Guest, G. M. \& Mirsky, I. A. (1942). J. biol. Chem. 144, 291.

Potter, V. R. \& Elvehjem, C. A. (1936). J. biol. Chem. 114, 495.

Quastel, J. H. \& Wheatley, A. H. M. (1935). Biochem. J. 29, 2773.

Rapoport, S. (1945). J. biol. Chem. 161, 429.

Rapoport, S., Leva, E. \& Guest, G. M. (1943a). J. biol. Chem. 149, 57.

Rapoport, S., Leva, E. \& Guest, G. M. (1943b). J. biol. Chem. 149, 65.

Rapoport, S. \& Nelson, N. (1945). J. biol. Chem. 161, 421:

Stone, W. E. (1943). J. biol. Chem. 149, 29.

Wieland, H. \& Rosenthal, C. (1943). Liebigs Ann. 554, 241.

\title{
The Estimation of Greatine
}

\author{
By A. H. ENNOR (Wellcome Research Fellow) AND L. A. STOCKEN \\ Department of Biochemistry, University of Oxford
}

(Received 1 October 1947)

During the course of an investigation into the metabolism of fatty livers (Ennor \& Stocken, 1948) it became desirable to identify, and subsequently to estimate, amounts of a very labile phosphorus com. pound present in the livers of normal guinea pigs and in others treated with carbon tetrachloride. Although phosphate liberated from organic phosphate compounds in acid molybdate is often considered to arise from phosphocreatine, there are other possibilities, and we endeavoured therefore to correlate the labile phosphorus with the creatine liberated following mild hydrolysis. It was decided to estimate the creatine as such rather than after conversion to creatinine, and an attempt was made to employ the method of Eggleton, Elsden \& Gough (1943). These authors have pointed out that trichloroacetic acid (TCA) extracts of liver contain inhibitory substances which prevent the estimation of creatine by the Barritt (1936) modification of the Vosges \& Proskauer (1898) reaction. The suggestion was also made that these inhibitors were the $\omega$-amino aliphatic acids.

In the fractionation of $T C A$ extracts of guinea-pig liver by means of barium (Le Page \& Umbreit, 1945) it was found that both the inhibitor and phosphocreatine were precipitated in the ethanol-insoluble fraction. An examination of this fraction indicated that the inhibitory substance or substances was more likely to be glutathione than an amino-acid as suggested by Eggleton et al. (1943). Such a supposition, because of the wide distribution of the tripeptide, necessarily casts some doubt upon the validity of the application of the $\alpha$-naphthol-diacetyl reaction to the estimation of creatine in tissues.

This communication is concerned with some experiments on the inhibition of the Barritt reaction by sulphydryl compounds and suggests a modification of the procedure of Eggleton et al. by means of which a more accurate determination of the creatine content of tissues may be made. 


\section{EXPERIMENTAL}

\section{Reagents}

Creatine hydrate. An A.R. specimen was recrystallized according to Hunter (1928) and its purity checked by $\mathrm{N}$ analysis.

Diacetyl. A stock solution of approx. $1 \%$ was prepared from A.R. dimethylglyoxime as described by Walpole (1911). This was diluted and used as described by Eggleton et al. (1943). No apparent loss in activity has been observed following 3 months' storage at $-1^{\circ}$.

$\alpha$-Naphthol. A faintly coloured A.R. sample has been used throughout. It was considered unnecessary to effect further purification by steam distillation. The solution of this compound and the volume used was, in all cases, as described by Eggleton et al. (1943).

Glutathione (GSH). This was a commercial specimen.

Oxidized glutathione (GSSG). This was prepared by bubbling $\mathrm{O}_{2}$ through a slightly alkaline solution of GSH of appropriate concentration until a negative nitroprusside reaction was obtained.

Benzyl mercaptan and methionine. These were gifts from the Ministry of Supply.

Cysteine ester hydrochloride. This compound was mentioned casually by Friedmann (1903) who gave no details of the synthesis. A mixture of $20 \mathrm{~g}$. cystine, $60 \mathrm{ml}$. conc. $\mathrm{HCl}$ $(36.5 \%$ w/v), $20 \mathrm{ml}$. water, $200 \mathrm{ml}$. ethanol and $20 \mathrm{~g}$. tin foil were gently refluxed until all the tin had dissolved. After removal of the tin with $\mathrm{H}_{2} \mathrm{~S}$, the solution was evaporated to dryness in vacuo and the residue dissolved in $150 \mathrm{ml}$. ethanol and saturated with dry $\mathrm{HCl}$ at $0^{\circ}$. Crystals of cysteine ester hydrochloride separated on standing overnight. Yield 24 g. (79\%). M.p. $128^{\circ}$. $\mathrm{SH}$ by $\mathrm{I}_{2}$ titration, $17 \cdot 7 \%$; calc. for $\mathrm{C}_{6} \mathrm{H}_{12} \mathrm{O}_{2} \mathrm{SNCl}, 17 \cdot 8 \%$.

Cystine ester hydrochloride. This was prepared according to the method of Friedmann (1903).

p-Chloromercuribenzoic acid was synthesized according to Whitmore \& Woodward (1932).

2:3-Dimercaptopropanol $(B A L)$ was obtained as described by Stocken (1947).

\section{Procedure}

This, apart from one minor modification, has followed the method described by Eggleton et al. (1943). Greater reproducibility is obtained if, after adjusting the volume of the creatine- $\alpha$-naphtholdiacetyl solution to $10 \mathrm{ml}$. in a narrow tube, the contents are transferred to a $6 \times 1$ in. tube for mixing and development of the colour. After $30 \mathrm{~min}$. development at room temperature $\left(18^{\circ}\right)$ the intensity of the colour was measured in $1 \mathrm{~cm}$. cells in the Hilger Spekker absorptiometer with Ilford filter no. 604 (spectrum green).

\section{Influence of monothiols on the Barritt reaction}

Cysteine ester hydrochloride. For preliminary tests and because of the small amount of GSH available, the initial experiments were carried out with cysteine ester hydrochloride. Varying amounts of this compound were added to tubes each containing
$1.0 \mathrm{ml}$. of $5 \times 10^{-4} \mathrm{M}$-creatine $(65.5 \mu \mathrm{g}$.). The percentage inhibition of colour development was then calculated and plotted against the molar ratio, cysteine ester : creatine.

The influence of cysteine ester on the colour produced by creatine, diacetyl and $\alpha$-naphthol is very marked, $60 \%$ inhibition being observed with a molar ratio of cysteine ester : creatine of $0.8: 1$.

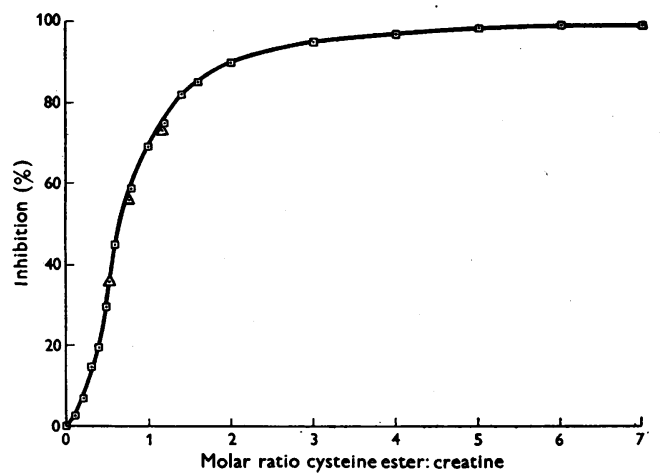

Fig. 1. Inhibition of the Barritt reaction by varying amounts of cysteine ester hydrochloride and glutathione. $65.5 \mu \mathrm{g}$. of creatine throughout. To all tubes were added $2.0 \mathrm{ml}$. $\alpha$-naphthol solution (1.0 g. $\alpha$-naphthol in $100 \mathrm{ml}$. of a solution containing $6.0 \mathrm{~g}$. $\mathrm{NaOH}+16 \mathrm{~g}$. $\mathrm{Na}_{2} \mathrm{CO}_{3}$ ) $+1.0 \mathrm{ml}$. of a 1 in 20 dilution of stock diacetyl + varying amounts of thiol. Adjusted to $10 \mathrm{ml}$. with water and colour measured after $30^{\circ} \mathrm{min}$. at room temperature. $\square$ denotes cysteine ester hydrochloride; $\Delta$ denotes glutathione.

Glutathione (GSH). To test the inhibitory effect of GSH three points on the cysteine ester curve were chosen and the colour produced by creatine in the presence of a GSH : creatine ratio of $0.5,0.8$ and $1.2 \mathrm{~mol}$. to 1 was determined. The points marked $\triangle$ in Fig. 1 were obtajned in this manner and are sufficiently close to the cysteine-ester inhibition curve to suggest that it is primarily the thiol group which is responsible for the inhibition of the Barritt reaction.

Benzyl mercaptan and 2:3-dimercaptopropanol. Two simple thiols were used in an attempt to show that the thiol group is the determining factor in the inhibition of the colour.

Table 1. Inhibition of Barritt reaction by simple thiols

\begin{tabular}{ccc} 
Molar ratio & \multicolumn{1}{c}{$\begin{array}{c}\text { Benzyl } \\
\text { thiol : creatine }\end{array}$} & BAL \\
0.5 & 47 & $11 \cdot 5$ \\
$0 \cdot 8$ & 66 & 17.5 \\
$1 \cdot 2$ & 84.5 & $24 \cdot 0$ \\
$2 \cdot 0$ & - & 46.5
\end{tabular}


The results (Table 1) obtained with benzyl mercaptan are similar to those found with cysteine ester and GSH and support the idea that the inhibition seen with the latter compounds is due primarily to the reactivity of the thiol group and not to the amino group. Further confirmation of this is given in the section dealing with the neutralization of the inhibitor. It will be noticed that the degree of inhibition given by BAL is very much less than that produced by the other compounds. It is likely that the inhibition is due to addition of the thiol group across some reactive double bond formed in the sequence of reactions leading to the coloured complex. If this is the case, it is not to be expected that BAL would be as efficient an inhibitor as benzyl mercaptan even if it be supposed that only one of the thiol groups in BAL is capable of such an addition.

It is clear from the foregoing experiments that thiol-containing compounds present in tissues will produce considerable interference with the estimation of creatine, and that the magnitude of the error introduced will depend on the ratio of thiol to creatine. Thus, in those tissues where the creatine content is low and the thiol content high, it would be anticipated that the method discussed would not even detect creatine.

\section{Effect of other sulphur-containing compounds}

It was considered unlikely that the oxidation of the SH group would eliminate the inhibition because of the well known tendency towards cleavage of the disulphide linkage in alkaline solution. Experiments with GSSG and cystine ester (Table 2) confirm this, although it will be noticed that GSSG produces a much greater degree of inhibition, and is apparently, therefore, much more susceptible to hydrolysis than is cystine ester.

Table 2. Disulphide inhibition of the Barritt reaction

\begin{tabular}{ccc}
$\begin{array}{c}\text { Molar ratio } \\
\text { disulphide : creatine }\end{array}$ & \multicolumn{2}{c}{ Inhibition (\%) } \\
\cline { 2 - 3 } $0 \cdot 25$ & - & GSSG \\
$0 \cdot 4$ & - & $22 \cdot 0$ \\
$0 \cdot 6$ & - & $34 \cdot 0$ \\
$1 \cdot 0$ & $3 \cdot 4$ & $50 \cdot 0$ \\
$2 \cdot 0$ & $5 \cdot 0$ & - \\
$4 \cdot 0$ & $9 \cdot 1$ & $81 \cdot 0$ \\
$8 \cdot 0$ & $18 \cdot 1$ & - \\
$16 \cdot 0$ & 31.9 & -
\end{tabular}

It is clear from these experiments that not only thiols, but any compound which generates a thiol on treatment with alkali, will seriously interfere with the estimation of creatine in tissue extracts. It is to be regretted that the only other sulphur compound of biological importance which we have had the opportunity of testing in this reaction was methionine. This produced an inhibition of about $5 \%$ when present in a molar ratio of 4 methionine : 1 creatine.

\section{Protection of the Barritt reaction from thiol inhibition}

It is apparent that when the molar ratio of $\mathrm{SH}$ to creatine exceeds $0.2-0.4$ (7-15\% inhibition), the successful application of the Barritt reaction will depend on the removal of SH groups. Compounds known to combine with thiol groups include iodoacetic acid, maleate, trivalent arsenicals and organic mercurials. Of these we preferred the mercurials because of the high rate of formation and stability of the resultant $R$-Hg-S $R^{\prime}$ compound in alkaline solution. $p$-Chloromercuribenzoic acid was chosen as a possible protective agent in order to ensure nonprecipitation of the $\mathrm{Hg}$ derivative.

Procedure. $1.0 \mathrm{ml}$. of a $5 \times 10^{-4} \mathrm{M}$-solution of creatine $(65.5 \mu \mathrm{g}$.) was added to a series of tubes, followed by $1.0 \mathrm{ml}$. of $4 \times 10^{-3} \mathrm{M}$-cysteine ester. This gave an initial ratio of cysteine ester : creatine of $8: 1$ (a ratio of $7: 1$ will produce $100 \%$ inhibition under these conditions, see Fig. 1). Varying volumes of an appropriate dilution of a $10^{-2} \mathrm{M}$ solution of $p$-chloromercuribenzoic acid $(C M B A)$ were then added to produce $C M B A$ : cysteine ester ratios from 0 to 2.0. $\alpha$-Naphthol and diacetyl were then added as before and the resultant colours estimated after $30 \mathrm{~min}$. All determinations were carried out in duplicate and the figures in Table 3 are the means of the values obtained.

Table 3. Protection afforded by p-chloromercuribenzoic acid $(C M B A)$ on the thiol inhibition of the Barritt reaction

(Degree of protection $=\mu$ g. creatine found $/ \mu \mathrm{g}$. creatine present $\times$ 100.)

$\begin{array}{cc}\text { Molar ratio } & \\ C M B A: \text { cysteine ester } & \text { Degree of protection } \\ 0 \cdot 1 & 0 \\ 0 \cdot 2 & 1 \cdot 5 \\ 0 \cdot 3 & 2 \cdot 0 \\ 0 \cdot 4 & 2 \cdot 8 \\ 0.5 & 2 \cdot 9 \\ 0 \cdot 6 & 5 \cdot 4 \\ 0.7 & 11 \cdot 8 \\ 0 \cdot 8 & 31 \cdot 5 \\ 0.9 & 73 \cdot 7 \\ 1.0 & 89 \cdot 6 \\ 2.0 & 92 \cdot 2\end{array}$

Increasing amounts of $C M B A$, as would be expected, lead to an increased removal of the inhibition produced by cysteine ester (Table 3). Complete removal of the inhibition, however, was not obtained even when the molar ratio of $C M B A$ : cysteine ester was $2: 1$. Any of the three following factors could be responsible for this effect: $(a)$ dissociation of the resultant $R$-Hg-S $R^{\prime},(b)$ the $R$-Hg-S $R^{\prime}$ itself, (c) the excess of the $C M B A$.

The degree of protection afforded by $C M B A$ against the effects of GSH, GSSG, benzyl mercaptan and BAL was similar to that obtained in the case of cysteine ester. 
Effect of ethyl $\alpha$-amino- $\beta$-(p-carboxyphenylmercurithio)-propionate and $p$-chloromercuribenzoic acid on the Barritt reaction. The ethyl $\alpha$-amino- $\beta$ ( $p$-carboxyphenylmercurithio)-propionate was not isolated, but prepared in solution by mixing equivalent amounts of $p$-chloromercuribenzoic acid and cysteine ester. Convenient amounts of suitable dilutions were then added to $1.0 \mathrm{ml}$. $5 \times 10^{-4} \mathrm{M}$ creatine $(65.5 \mu \mathrm{g}$.). The subsequent procedure was as described earlier.

Table 4 . Inhibition of the Barritt reaction by $p$ chloromercuribenzoic acid $(C M B A)$ and ethyl $\alpha$ amino- $\beta$-( $p$-carboxyphenylmercurithio)-propionate $(R$-Hg-SR $)$

Molar ratio
compound : creatine
$0 \cdot 5$
$1 \cdot 0$
$2 \cdot 0$
$4 \cdot 0$
$8 \cdot 0$
$10 \cdot 0$
$16 \cdot 0$
$32 \cdot 0$

\begin{tabular}{|c|c|}
\hline \multicolumn{2}{|c|}{ Inhibition (\%) } \\
\hline$R-\mathrm{Hg}-\mathrm{S} R^{\prime}$ & $C M B A$ \\
\hline 0 & $\mathbf{0}$ \\
\hline 0 & 0 \\
\hline 0 & $1 \cdot 7$ \\
\hline 4.9 & 4.5 \\
\hline $5 \cdot 3$ & $6 \cdot 1$ \\
\hline - & $7 \cdot 4$ \\
\hline $\begin{array}{r}8.2 \\
11 \cdot 1\end{array}$ & - \\
\hline & \\
\hline
\end{tabular}

The results of this experiment (Table 4) indicete that some inhibition is to be expected when the ratio of either the complex, or of the $C M B A$, to creatine exceeds $2: 1$. Since, however, a ratio of $4: 1$ only produces an inhibition of $5 \%$ and a ratio of $2 \mathrm{~mol}$. $C M B A$ to $1 \mathrm{~mol}$. cysteine affords $92 \%$ protection, it is clear that the error introduced is small compared with that obtained when free thiol compounds are present.

Stoicheiometric relationship of the cysteine ester inhibition. It was considered worth while to determine the colour developed by varying amounts of creatine in the presence of varying amounts of cysteine ester when the relative amounts of each were maintained at a constant ratio. A molar ratio of cysteine ester to creatine of $0.6: 1$ was chosen since at this value the inhibition expected is $44 \cdot 8 \%$ (Fig. 1).

The strictly linear relationship between the amount of creatine and the optical density is shown in Fig. 2. In the presence of cysteine it will be noticed that there is a distinct diminution in the inhibition at low concentrations of the thiol (Fig. 3).

If it is true that interference with the production of the coloured compound is due to a preferential reaction of some intermediate compound with the thiol then it would be expected, under the conditions of this experiment, that the percentage inhibition would remain constant. This, however, is not the case, and the explanation is probably to be found in the small absolute amount of cysteine ester which is present at the lower creatine levels. Thus at $8 \cdot 18 \mu \mathrm{g}$. of creatine there are only $5.6 \mu \mathrm{g}$. of cysteine ester in a volume of $10.0 \mathrm{ml}$., and it must be considered unlikely that such a small amount would remain in the reduced state. The actual ratio of cysteine ester to creatine would thus be less than $0 \cdot 6: 1$. Reference to Fig. 1 shows that a reduction of this ratio to $0.4: 1$ would account for the low inhibition seen at the $8 \cdot 18 \mu \mathrm{g}$. level of creatine.

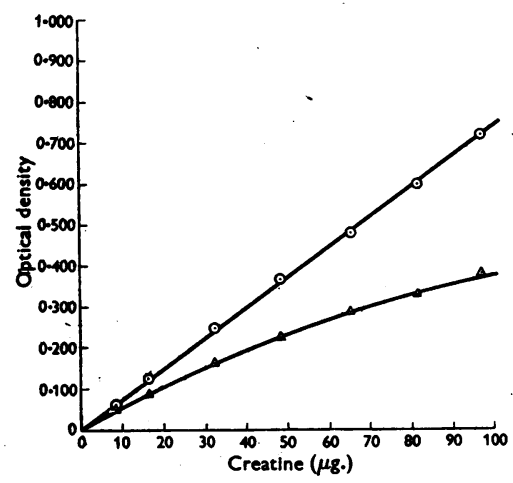

Fig. 2. Comparison of the colour produced by varying amounts of creatine in the absence $\odot$ and the presence $\triangle$ of a molar ratio of cysteine ester : creatine of $0.6: 1$.

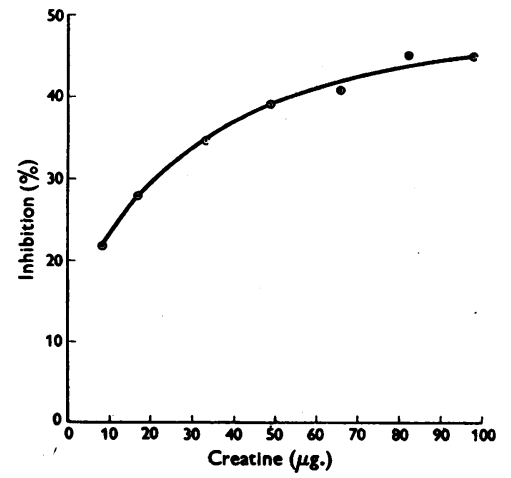

Fig. 3. Variation in the inhibition of the Barritt reaction in the presence of a constant ratio of cysteine ester : creatine of $0 \cdot 6: 1$.

\section{Application of the method to the estimation of creatine in tissue extracts}

Well fed, adult, male rats of about $300 \mathrm{~g}$. body weight were stunned by a blow on the head and the neck vessels severed. Samples of the various tissues were weighed in a mortar of the Potter \& Elvehjem (1936) type, and homogenized with $5 \mathrm{ml}$. of $10 \%$ (w/v) trichloroaceticacid (TCA). After centrifugation, the residue was re-extracted with $10 \mathrm{ml}$. of $5 \% T C A$. The combined supetnatant fluids were made up to $25.0 \mathrm{ml}$. with water and filtered prior to the removal of samples' for estimation. 
Procedure. The creatine was determined in suitable samples of the TCA extracts both in the presence and absence of $C M B A$. To obtain some idea of the absolute amounts of reducing substances present, and hence the amount of $C M B A$ necessary to combine with the SH present, samples of the $T C A$ extracts were titrated with $0.01 \mathrm{~N}$-iodine after the addition of $0.5 \mathrm{vol}$. N-HCl (to facilitate comparison with the previous experiments, the iodine titres are expressed as equivalents of cysteine ester). If it be assumed that the reducing substances are entirely
$C M B A$. Thus small intestine, kidney, lung and spleen with ratios (obviously too high, cf. Fig. 1), of 2.6-7.5 : 1 show increases from 70 to $250 \%$, and the other tissues with ratios of $0.05-0.5: 1$ have increases of $2-16 \%$. In the case of liver tissue, a mean ratio of $37 \cdot 2: 1$ will prevent the estimation of creatine in the absence of $C M B A$ and thus the addition of this compound must lead to an infinite increase.

Table 5. Creatine content of rat tissues found in the presence and absence of $C M B A$

\begin{tabular}{|c|c|c|c|c|c|}
\hline \multirow[b]{2}{*}{ Tissue } & \multirow{2}{*}{$\begin{array}{l}\text { Cysteine } \\
\text { ester } \\
\text { equivalent } \\
\text { (mg./100 g.) }\end{array}$} & \multicolumn{2}{|c|}{$\begin{array}{c}\text { Creatine } \\
\text { (mg./100 g.) }\end{array}$} & \multirow[b]{2}{*}{$\begin{array}{c}\text { Molar ratio } \\
\text { cysteine ester } \\
\text { equivalent : creatine }\end{array}$} & \multirow{2}{*}{$\begin{array}{c}\text { Increase } \\
\text { with } \\
C M B A \\
(\%)\end{array}$} \\
\hline & & $\begin{array}{c}C M B A \\
\text { absent }\end{array}$ & $\begin{array}{l}C M B A \\
\text { present }\end{array}$ & & \\
\hline $\begin{array}{r}\text { Liver (1) } \\
\text { (2) }\end{array}$ & $\begin{array}{l}185 \\
244\end{array}$ & $\begin{array}{l}\mathbf{0} \\
\mathbf{0}\end{array}$ & $\begin{array}{l}4 \cdot 6 \\
3 \cdot 8\end{array}$ & $\begin{array}{l}28 \cdot 8 \\
45 \cdot 7\end{array}$ & $\infty$ \\
\hline $\begin{array}{r}\text { Spleen (1) } \\
(2)\end{array}$ & $\begin{array}{l}161 \\
181\end{array}$ & $\begin{array}{l}\mathbf{5} \cdot 9 \\
\mathbf{3} \cdot 9\end{array}$ & $\begin{array}{l}15 \cdot 8 \\
15 \cdot 3\end{array}$ & $\begin{array}{l}7 \cdot 2 \\
8 \cdot 4\end{array}$ & $\begin{array}{l}197 \\
292\end{array}$ \\
\hline $\begin{array}{r}\text { Kidney (1) } \\
\text { (2) }\end{array}$ & $\begin{array}{l}139 \\
159\end{array}$ & $\begin{array}{l}7 \cdot 7 \\
9 \cdot 2\end{array}$ & $\begin{array}{l}20 \cdot 5 \\
22 \cdot 9\end{array}$ & $\begin{array}{l}4 \cdot 8 \\
4 \cdot 9\end{array}$ & $\begin{array}{l}166 \\
150\end{array}$ \\
\hline Lung (1) & $\begin{array}{l}124 \\
149\end{array}$ & $\begin{array}{l}6 \cdot 0 \\
5 \cdot 8\end{array}$ & $\begin{array}{l}13 \cdot 0 \\
11 \cdot 8\end{array}$ & $\begin{array}{l}6 \cdot 8 \\
9 \cdot 0\end{array}$ & $\begin{array}{l}117 \\
104\end{array}$ \\
\hline Smooth muscle (small intestine) (1) & $\begin{array}{l}124 \\
147\end{array}$ & $\begin{array}{l}24 \cdot 2 \\
20 \cdot 7\end{array}$ & $\begin{array}{l}40 \cdot 4 \\
34 \cdot 8\end{array}$ & $\begin{array}{l}2 \cdot 2 \\
3 \cdot 0\end{array}$ & $\begin{array}{l}67 \\
68\end{array}$ \\
\hline $\begin{array}{r}\text { Testis (1) } \\
\text { (2) }\end{array}$ & $\begin{array}{l}172 \\
178\end{array}$ & $\begin{array}{l}248 \cdot 0 \\
260 \cdot 0\end{array}$ & $\begin{array}{l}295 \cdot 0 \\
299 \cdot 0\end{array}$ & $\begin{array}{l}0.4 \\
0 \cdot 4\end{array}$ & $\begin{array}{l}16 \cdot 5 \\
15\end{array}$ \\
\hline $\begin{array}{r}\text { Brain (1) } \\
(2)\end{array}$ & $\begin{array}{r}84 \\
136\end{array}$ & $\begin{array}{l}114 \cdot 5 \\
115 \cdot 0\end{array}$ & $\begin{array}{l}130 \cdot 0 \\
133 \cdot 0\end{array}$ & $\begin{array}{l}0.5 \\
0.7\end{array}$ & $\begin{array}{l}14 \\
15\end{array}$ \\
\hline $\begin{array}{l}\text { Cardiac muscle (ventricle) (1) } \\
\text { (2) }\end{array}$ & $\begin{array}{l}110 \\
147\end{array}$ & $\begin{array}{l}170 \cdot 0 \\
197 \cdot 0\end{array}$ & $\begin{array}{l}192 \cdot 0 \\
212 \cdot 0\end{array}$ & $\begin{array}{l}0.4 \\
0.5\end{array}$ & $\begin{array}{r}13 \\
7\end{array}$ \\
\hline Skeletal muscle (1) & $\begin{array}{l}46 \\
39\end{array}$ & $\begin{array}{l}516 \cdot 0 \\
500 \cdot 0\end{array}$ & $\begin{array}{l}520 \cdot 0 \\
511 \cdot 0\end{array}$ & $\begin{array}{l}0.06 \\
0.05\end{array}$ & $\begin{array}{l}2 \\
2\end{array}$ \\
\hline
\end{tabular}

thiol in character the addition of an equivalent amount of $C M B A$ will ensure an excess of the reagent. The figures quoted in Table 5 are the means of at least two determinations on each sample.

It will be noticed that in the case of kidney, spleen, lung and small intestine, the addition of $C M B A$ produced a considerable increase in the amount of creatine estimated (Table 5). In the case of liver, the addition of $C M B A$ now renders possible the determination of the creatine present, zero values being recorded in its absence. With the remaining tissues investigated, voluntary muscle, testis, brain and cardiac muscle, the increases are not as great, a maximum mean increase of only $15 \cdot 7 \%$ being present in the case of testis.

The magnitude of the increase in the amount of creatine measurable in the presence of $C M B A$ will -depend on the relative amounts of thiol and creatine. The method employed to obtain the cysteine ester equivalent, and thus the ratio of this to creatine, will lead to a high result. Nevertheless it is of some interest to note that there is a fair correlation between the ratios so obtained and the percentage increase in the creatine measured in the presence of
Although the figures for the creatine content of the various tissues examined are the maximum obtainable in the presence of $C M B A$, they do not necessarily represent the true creatine values because of the possible inhibition by substances other than the $R$-Hg-S $R^{\prime}$ compound formed and the excess $C M B A$ present. This possibility was examined by attempting to recover $20 \mu \mathrm{g}$. of creatine which were added to samples before analysis.

Appropriate samples of the $T C A$ extracts were taken in quadruplicate, and to each set of tubes $2.0 \mathrm{ml}$. of $5 \times 10^{-\mathrm{R}} \mathrm{M}$ $C M B A(1426 \mu \mathrm{g}$.) were added. To two of the tubes in each series $20 \mu \mathrm{g}$. of creatine were added. $\alpha$-Naphthol and diacetyl were added as before and the colour measured after $30 \mathrm{~min}$. In view of the inhibition pr)duced by the excess of $C M B A$, the amount of creatine was obtained by reference to a standard curve prepared by measuring the colour produced by known amounts of creatine in the presence of $1426 \mu \mathrm{g}$. of $C M B A$.

The recoveries of $20 \mu \mathrm{g}$. of added creatine (Table 6) indicate that this procedure will give values for the creatine contents of tissues which are reasonably close to those actually present. 
Table 6. Recovery of $20 \mu$ g. creatine added to trichloroacetic acid extracts of various rat tissues in the presence of $C M B A$

\begin{tabular}{lccc}
\multicolumn{1}{c}{ Tissue } & $\overbrace{\begin{array}{c}\text { No } \\
\text { addition }\end{array}}^{\text {Creatine found }(\mu \mathrm{g} .)}$ & $\begin{array}{c}\text { +20 } \mu \mathrm{g} . \\
\text { creatine }\end{array}$ & $\begin{array}{c}\text { Recovery } \\
\text { of added } \\
\text { creatine } \\
(\%)\end{array}$ \\
Muscle & $28 \cdot 4$ & $48 \cdot 4$ & 100 \\
Testis & $18 \cdot 0$ & $37 \cdot 4$ & 97 \\
Lung & $13 \cdot 6$ & $31 \cdot 6$ & 90 \\
Brain & $22 \cdot 2$ & $41 \cdot 0$ & 94 \\
Cardiac muscle & $20 \cdot 2$ & $41 \cdot 0$ & 104 \\
$\quad$ (ventricle) & & & \\
Liver & $18 \cdot 2$ & $36 \cdot 2$ & 90 \\
Spleen & $13 \cdot 2$ & $30 \cdot 8$ & 88 \\
Kidney & $43 \cdot 4$ & $60 \cdot 8$ & 87 \\
Smooth muscle & $41 \cdot 3$ & $59 \cdot 9$ & 93 \\
(small intestine) & & &
\end{tabular}

As a matter of interest the behaviour of the $\alpha$-naphthol-diacetyl method for the estimation of creatine in whole blood has also been studied (Table 7). liver extracts and in urine. They further state that extracts of most animal tissues, with the exception of liver, 'appear to contain insignificant amounts of interfering substances'. An examination of the ethanol-insoluble barium salts obtained from $T C A$ extracts of liver led us to the conclusion that GSH was more likely to be the agent responsible for the inhibitory effect, and further that it is the $\mathrm{SH}$ group which is the determining factor.

The inhibitory influence of SH-containing compounds on the $\alpha$-naphthol-diacetyl reaction for the estimation of creatine is very striking and depends on the molar ratio of $\mathrm{SH}$ : creatine. In the estimation of creatine in spleen, kidney, lung and intestine, the $\mathrm{SH}$ : creatine ratio is sufficient to produce errors ranging from 60 to $250 \%$.

The inhibitory action of $\mathrm{SH}$ can be removed almost completely by the addition of $p$-chloromercuribenzoic acid, and the figures obtained in the presence of this compound suggest that the method, so modified, is now capable of giving creatine values

Table 7. Creatine content of whole blood found in the presence and absence of $C M B A$

(10.91 g. of rabbit blood $+10 \mathrm{ml}$. of $10 \%(\mathrm{w} / \mathrm{v})$ trichloroacetic acid, proteins separated by centrifugation. The insoluble protein residue re-extracted with a further $10 \mathrm{ml}$. of $5 \%$ trichloroacetic acid, centrifuged and the supernatant fluids combined and made up to $25.0 \mathrm{ml}$. with water. Filtered. $2.0 \mathrm{ml}$. samples taken in all cases.)

\begin{tabular}{|c|c|c|c|c|}
\hline \multicolumn{3}{|c|}{ Creatine in sample ( $\mu \mathrm{g})}$. & \multirow[b]{2}{*}{$\begin{array}{c}\text { Increase in presence } \\
\text { of } C M B A \\
\quad(\%)\end{array}$} & \multirow[b]{2}{*}{$\begin{array}{c}\text { Recovery } \\
(\%)\end{array}$} \\
\hline$C M B A$ & $C M B A$ present & $\begin{array}{l}+20 \mu \mathrm{g} \text {. creatine, } \\
C M B A \text { present }\end{array}$ & & \\
\hline $14 \cdot 6$ & $18 \cdot 6$ & $36 \cdot 2$ & $27 \cdot 4$ & 88 \\
\hline
\end{tabular}

Creatine, $\mathrm{mg} . / 100 \mathrm{~g}$. blood $=\mathbf{2 \cdot 4}$ (calculated from creatine measured in sample in the presence of $C M B A)$.

Here again the recovery of added creatine may be carried out satisfactorily and is comparable in magnitude with that observed in tissue extracts. The influence of $\mathbf{S H}$ is again well illustrated by the $27 \%$ increase in the amount of creatine measured in the presence of added $C M B A$.

Some experiments have been carried out with urine from normal males, young children and pregnant females. These have been neither sufficiently numerous nor comprehensive to quote in detail, but some of the preliminary results are of interest. It has been found that some degree of inhibition is present in $1.0 \mathrm{ml}$. of urine as judged by the increased values in the presence of $C M B A$. These increases were variable and have not been correlated with other factors, but were of the order of $10 \%$. $100 \%$ recoveries of added creatine were obtained by the addition of $C M B A$, and it therefore appears possible that this modification may prove useful for the estimation of creatine in urine.

\section{DISCUSSION}

It has been suggested by Eggleton et al. (1943) that $\omega$-amino-acids may be responsible for the failure of the Barritt reaction to estimate creatine in $T C A$ - which are close to the true values. An effect, similar to that obtained with this substance, could probably be gained by the addition of other organic mercurials and, in fact, by any substance reacting with $\mathrm{SH}$ groups to give a complex 'stable to alkali; but since $p$-chloromercuribenzoic acid behaved satisfactorily in our hands this has been used exclusively.

The results of experiments with pure $\mathrm{SH}$ compounds and SH-containing tissue extracts in the presence of $p$-chloromercuribenzoic acid strongly suggest that $\mathrm{SH}$ compounds are the only inhibitors of importance as far as the application of the Barritt reaction to tissue extracts is concerned. This conclusion is further strengthened by the fact that, in most instances, recoveries of known amounts of added creatine were $90 \%$ or greater. Although Eggleton et al. (1943) have observed a $50 \%$ reduction of the colour produced by $30 \mu \mathrm{g}$. of creatine in the presence of $4 \mathrm{mg}$. of glycine it seems improbable that such amounts of any amino-acid could be present in the usual samples taken for estimation of creatine in $T C A$-tissue extracts.

The only body fluids examined have been whole blood and urine, and in both cases the addition of $C M B A$ appears to overcome the inhibitors which 
are present. The suggestion of Walpole (1911) that it is the $\mathrm{NH}_{3}$ which interferes with the reaction in normal urine has not been confirmed.

It follows from the high degree of sensitivity of this reaction to the presence of sulphydryl compounds that use might be made of this fact for the detection, and possibly the estimation, of small amounts of SH and alkali-labile SS substances. Experiments are in progress to test this possibility.

As Barritt (1936) has pointed out, the reaction between diacetyl, $\alpha$-naphthol and creatine to form a coloured product is also given by other guanido compounds. Eggleton et al. (1943) have stated that arginine, guanidine and glycocyamine produce about one ninth of the colour produced by equivalent amounts of creatine. All results quoted in this communication have been calculated on the assumption that creatine alone produces the colour measured. It is believed that the error introduced by such an assumption is small. However, in the application of the revised method, the possibility of increased amounts of other guanido compounds in pathological states must be borne in mind.

\section{SUMMARY}

1. The $\alpha$-naphthol-diacetyl reaction for the estimation of creatine has been investigated.

2. The inhibition, which has been noted by other workers to occur when the estimation of the creatine content of trichloroacetic acid extracts of liver is attempted, has been shown to be due to the presence of sulphydryl compounds and, by inference, to the presence of glutathione.
3. The inhibition by sulphydryl compounds depends on the molar ratio of the sulphydryl compound to creatine, and is therefore most marked in the liver where the creatine content is low and the glutathione content high.

4. The ratio of sulphydryl compounds to creatine, in several tissues investigated, is sufficiently high to produce very gross errors in the estimation of creatine by this method. Exceptions are found in voluntary and cardiac muscle, brain and testis, but even here the method is subject to error.

5. The presence of disulphide compounds such as GSSG also produces an inhibition due, presumably, to the tendency of the disulphide linkage to split in alkaline solution.

6. The inhibition produced by sulphydryl compounds can be almost completely removed by the addition of $p$-chloromercuribenzoic acid; both this compound and that formed by its reaction with the sulphydryl compounds possess weak inhibitory powers.

7. The creatine content of various tissues, blood and urine has been determined both in the presence and in the absence of $p$-chloromercuribenzoic acid and an assessment made of the errors introduced by the omission of this compound.

8. The recoveries of creatine added to extracts of various tissues, blood and urine are mostly in excess of $90 \%$, thus indicating the general applicability of the modified method.

We wish to express our thanks to the Chief Scientist of the Ministry of Supply for gifts of methionine and benzyl mercaptan and to Messrs E. Facer and S. Moorbath for skilled technical assistance.

\section{REFERENCES}

Barritt, M. M. (1936). J. Path. Bact. 42, 441.

Eggleton, P., Elsden, S. R. \& Gough, N. (1943). Biochem. J. 37, 526.

Ennor, A. H. \& Stocken, L. A. (1948). Biochem. J. 42, 549. Friedmann, E. (1903). Beitr. chem. Physiol. Path. 3, 1.

Hunter, A. (1928). Creatine and Creatinine. London: Longmans Green.

Le Page, G. A. \& Umbreit, W. W. (1945). Manometric Techniques and Related Methods for the Study of Tissue
Metabolism, by W. W. Umbreit, R. H. Burnis \& J. F. Stauffen. Minneapolis: Burgess Publishing Co.

Potter, V. R. \& Elvehjem, C. A. (1936). J. biol. Chem. 114, 495.

Stocken, L. A. (1947). J. chem. Soc. p. 592.

Vosges, O. \& Proskauer, B. (1898). Z. Hyg. InfektKr. 28, 20.

Walpole, G. S. (1911). J. Physiol. 42, 301.

Whitmore, F. C. \& Woodward, G. E. (1932). Organic Synth. Collective 1, 153. 